\title{
Buccal Swab
}

National Cancer Institute

\section{Source}

National Cancer Institute. Buccal Swab. NCI Thesaurus. Code C113747.

The collection of cells from the inside of a person's cheek using a swab collection device. 